\title{
PHYSIOLOGY OF NEMATODES
}




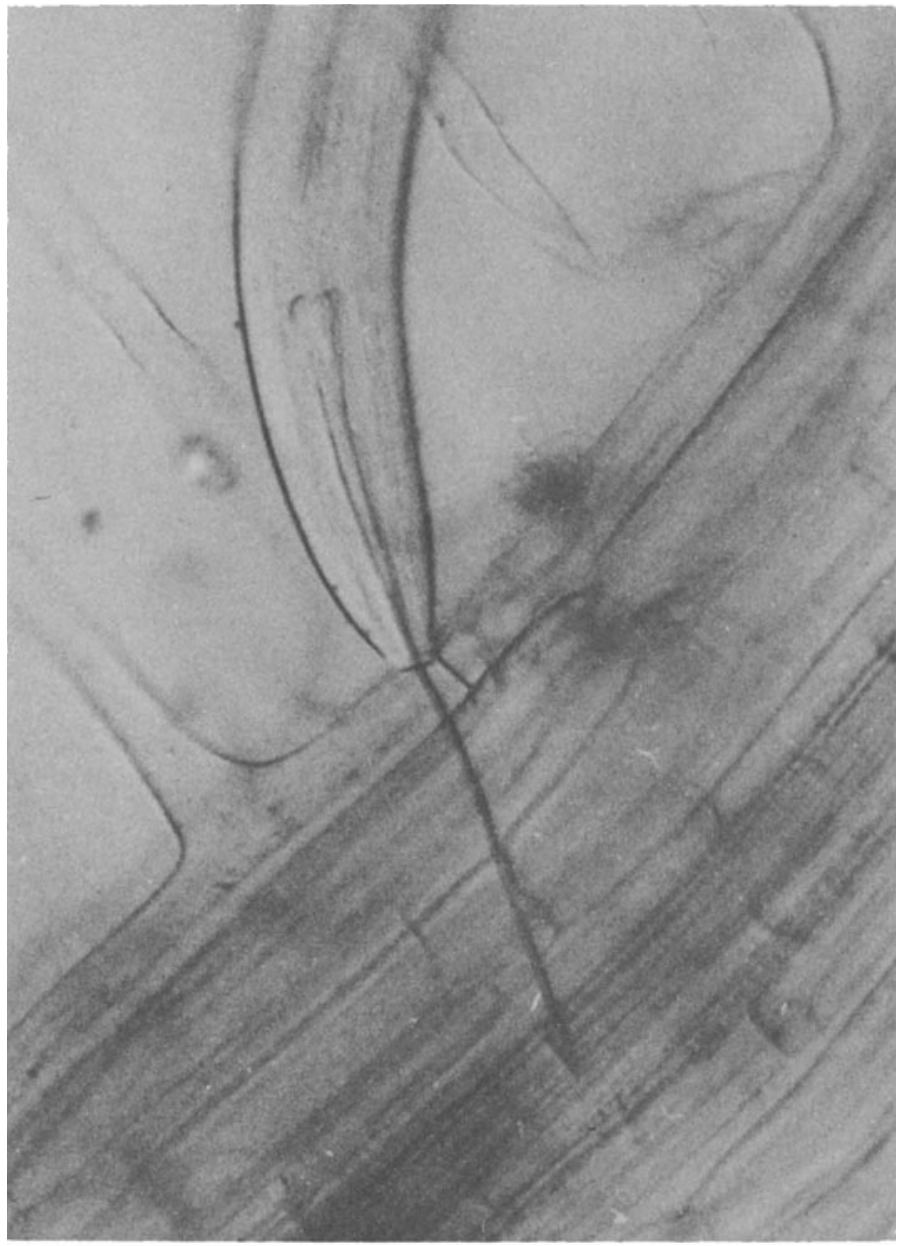

Frontispiece Plant-parasitic nematode (Xiphinema) feeding by means of its stylet upon the contents of the vascular tissue in a plant root. (Courtesy of D. L. Trudgill.) 


\title{
PHYSIOLOGY OF NEMATODES
}

\author{
D. L. LEE \\ Professor of Agricultural Zoology \\ and \\ H. J. ATKINSON \\ Lecturer \\ Department of Pure and Applied Zoology, \\ University of Leeds
}

Second Edition 
D. L. Lee 1965

() 2nd Edition D. L. Lee and H. J. Atkinson 1976

Softcover reprint of the hardcover 2nd edition 1976

All rights reserved. No part of this publication may be reproduced or transmitted, in any form or by any means, without permission.

First published 1965 by

Oliver and Boyd Ltd

2nd Edition published 1976 by

THE MACMILLAN PRESS LTD

London and Basingstoke

Associated companies in New York Dublin

Melbourne Johannesburg and Madras

ISBN 978-1-349-02669-2 ISBN 978-1-349-02667-8 (eBook)

DOI 10.1007/978-1-349-02667-8

This book is sold subject to the standard conditions of the Net Book Agreement. 


\section{Contents}

Preface

ix

1. Introduction 1

1.1. General Biology 1

1.2. The Organisation of the Nematode Body 3

1.2.1. Cuticle 3

1.2.2. Hypodermis 4

1.2.3. Muscles 5

1.2.4. Nervous system 6

1.2.5. Pseudocoelom 7

1.2.6. Pseudocoelomocytes 7

1.2.7. Alimentary system 7

1.2.8. Excretory system 8

1.2.9. Reproductive system 9

1.2.10. Hypodermal, caudal and rectal glands 10

2. Cuticle, Moulting and Growth 11

2.1. The Cuticle 11

2.1.1. Structure 11

2.1.2. Composition 14

2.2. Moulting and Ecdysis 15

2.2.1. Introduction 15

2.2.2. The stimulus 15

2.2.3. Formation of the new cuticle and ecdysis 16

2.2.4. Neurosecretory control of moulting and ecdysis 21

2.2.5. Ecdysis of ensheathed juveniles 22

2.3. Growth 25

3. Feeding and Digestive Physiology 28

3.1. The Alimentary Canal 28

3.1.1. Stomodaeum 28

3.1.2. The functioning of the pharynx as a pump 34

3.1.3. Intestine 36

3.1.4. Proctodaeum 38

3.2. Feeding 38

3.2.1. Microbivorous and saprophagous 38

3.2.2. Phytophagous and mycophagous $\quad 39$

3.2.3. Carnivorous 43 
3.2.4. Entomophagous 44

3.2.5. Parasites of vertebrates 45

3.3. Digestive Enzymes 48

3.3.1. Enzymes in the pharynx 48

3.3.2. Enzymes in the intestine 50

3.3.3. Enzymes in the sub-ventral (excretory) glands 52

3.4. Secretion in the Intestine 53

3.5. Uptake of Nutrients 53

3.6. Nutrient Requirements and Growth In Vitro 55

3.7. Defecation 56

3.8. Anti-enzymes and Anti-coagulants 56

4. Metabolism 58

4.1. Carbohydrate Metabolism 58

4.1.1. Distribution of carbohydrates $\quad 58$

4.1.2. Intermediary metabolism 60

4.1.3. Glycolysis: the Embden-Meyerhof pathway 62

4.1.4. Pasteur effect 63

4.1.5. Production of lactic acid and the oxygen debt 63

4.1.6. Oxidative decarboxylation: the tricarboxylic acid cycle 64

4.1.7. The TCA cycle in nematodes 64

4.1.8. Alternative pathways of carbohydrate metabolism in

4.1.9. The electron transport system: oxidative phosphorylation 70

4.1.10. The electron transport system in nematodes 70

4.1.11. Electron transport in Ascaris $\quad 72$

$\begin{array}{ll}\text { 4.1.12. P/O ratio } & 73\end{array}$

4.1.13. The pentose-phosphate pathway $\quad 74$

4.1.14. Glycogenesis and gluconeogenesis $\quad 75$

4.1.15. Nucleotides and nucleosides $\quad 75$

4.1.16. Production of organic acids 76

$\begin{array}{ll}\text { 4.2. Lipid Metabolism } & 76\end{array}$

4.2.1. Distribution of lipids $\quad 76$

$\begin{array}{ll}\text { 4.2.2. Lipid metabolism . } & 79\end{array}$

4.3. Protein Metabolism 80

4.3.1. Distribution of proteins $\quad 80$

$\begin{array}{ll}\text { 4.3.2. Protein metabolism } & 83\end{array}$

4.4. Respiratory Physiology $\quad 85$

4.4.1. Diffusion of oxygen $\quad 85$

4.4.2. Factors which influence oxygen demand 86

4.4.3. Availability of oxygen $\quad 88$

4.4.4. Respiration in low-oxygen regimes $\quad 89$

4.4.5. Haemoglobin 91 
4.5. Pharmacology 93

4.5.1. Glucose uptake and glycolysis 95

4.5.2. TCA cycle, succinate formation and phosphorylation 95

5. Osmotic and Ionic Regulation: Excretion 97

5.1. Osmotic Regulation 97

$\begin{array}{ll}\text { 5.1.1. Introduction } & 97\end{array}$

5.1.2. Volume regulation in nematodes $\quad 97$

5.1.3. Permeability to water 103

5.1.4. Desiccation survival 103

5.2. Ionic Regulation 104

5.2.1. Introduction 104

5.2.2. Ionic regulation in nematodes 105

5.2.3. Permeability to solutes 107

$\begin{array}{ll}\text { 5.3. Excretion } & 109\end{array}$

5.3.1. Introduction 109

5.3.2. Products of nitrogen catabolism in nematodes 109

5.3.3. Other excretory products 112

5.3.4. Excretion of nitrogenous waste 112

5.3.5. Functions of the excretory system 113

6. Reproductive Physiology and Hatching 116

6.1. Reproductive Physiology 116

6.1.1. The male system and spermatogenesis 116

6.1.2. Sex attraction 119

$\begin{array}{ll}\text { 6.1.3. Copulation } & 120\end{array}$

6.1.4. The female system and oogenesis $\quad 120$

6.1.5. Fertilisation 121

6.1.6. Structure and formation of the egg shell 122

6.1.7. Egg laying $\quad 125$

6.2. Hatching 125

6.2.1. Emergence of juveniles from eggs 125

6.2.2. General environmental effects on hatching 127

6.2.3. Specific hatching stimuli: temperature 128

$\begin{array}{ll}\text { 6.2.4. Specific hatching stimuli: chemical } & 129\end{array}$

7. Neuro-muscular Physiology 133

7.1. Muscles 133

$\begin{array}{ll}\text { 7.2. The Nervous System } & 136\end{array}$

$\begin{array}{ll}\text { 7.2.1. Structure } & 136\end{array}$

7.2.2. The nerve-muscle junction 138

7.2.3. Transmission along nerves 138

7.2.4. Neuro-muscular and synaptic transmission 138

$\begin{array}{ll}\text { 7.3. Pharmacology } & 142\end{array}$ 
8. Locomotion 145

$\begin{array}{ll}\text { 8.1. The Hydrostatic Skeleton } & 145\end{array}$

$\begin{array}{ll}\text { 8.2. Sinusoidal Movement } & 147\end{array}$

$\begin{array}{ll}\text { 8.2.1. Swimming } & 147\end{array}$

8.2.2. Movement in water films (crawling) 149

8.2.3. Movement in soils 152

8.2.4. Movement within animals 155

8.2.5. Movement within the egg 155

8.3. Other Forms of Movement 156

$\begin{array}{ll}\text { 8.4. Dispersal Mechanisms } & 158\end{array}$

9. Sense Organs and Behaviour 161

$\begin{array}{ll}\text { 9.1. Sense Organs } & 161\end{array}$

$\begin{array}{ll}\text { 9.1.1. Introduction } & 161\end{array}$

$\begin{array}{ll}\text { 9.1.2. Mechanoreceptors } & 161\end{array}$

9.1.3. Chemoreceptors 164

$\begin{array}{ll}\text { 9.1.4. Photoreceptors } & 167\end{array}$

$\begin{array}{lr}\text { 9.2. Behaviour } & 168\end{array}$

$\begin{array}{ll}\text { 9.2.1. Responses to chemicals } & 169\end{array}$

9.2.2. Response to mechanical stimulation 172

$\begin{array}{lr}\text { 9.2.3. Reactions to heat } & 172\end{array}$

$\begin{array}{ll}\text { 9.2.4. Responses to light } & 173\end{array}$

9.2.5. Responses to an electrical field 174

9.2.6. Responses to gravity 175

9.2.7. Response to a moisture gradient 175

$\begin{array}{ll}\text { 9.3. Whole Patterns of Behaviour } & 175\end{array}$

9.3.1. Location and penetration of host plants 176

$\begin{array}{ll}\text { 9.3.2. Location and penetration of host animals } & 177\end{array}$

$\begin{array}{ll}\text { Appendix } & 179\end{array}$

References $\quad 187$

Index $\quad 200$ 


\section{Preface}

At one time nematodes were studied almost exclusively by plant pathologists and by parasitologists, but they are now also studied by biochemists, biophysicists, geneticists, immunologists, molecular biologists, pharmacologists and neurophysiologists, who see the nematode as an exciting and challenging animal suitable for many fields of fundamental and applied research.

During the ten years that have elapsed since the appearance of the first edition of this book, a large number of research papers and reviews and several books, which describe various aspects of the biochemistry, physiology, functional morphology and ecology of free-living and parasitic nematodes, have been published. This book is intended to be an introduction to the physiology, biochemistry and structure of nematodes for undergraduate students and their teachers, and is not intended as an exhaustive review of the subject, although it is hoped that research workers in the field may also find it useful.

The information in this book is based on many publications. Unfortunately, it has not been possible to include references to all of them; consequently many references are to books, reviews and recent papers and these will introduce the reader to the earlier, more detailed, literature. For this reason, reference to an author in the text does not imply that this author was the first to have made the observation in question.

We are indebted to Professor A. O. Anya, Dr K. S. Cheah, Dr D. J. McLaren, Mr D. R. Newall, Dr D. J. Wright and Dr K. A. Wright, who allowed us to read some of their work prior to publication, and to Mrs Marjorie Miles who typedthe manuscript.

We are also indebted to the following for permission to reproduce illustrations and tables: Academic Press Inc. for figure 5.4 from Experimental Parasitology, figure 2.3 from The Structure of Nematodes by A. F. Bird, figure 2.6 from The nature of Parasitism by W. F. Rogers, figure 4.3 from Comparative Biochemistry of Parasites edited by H. Van den Bossche, figure 7.5 from Chemical Zoology vol. 3 edited by M. Florkin and B. T. Scheer, figures 5.1, 5.2 and 5.6 from The Organization of Nematodes edited by N. A. Croll, table 4.2 from Advances in Parasitology and table 2.1 from Archives of Biochemistry and Biophysics; Cambridge University Press for figures 1.3, 2.2, 2.7, 3.6, 3.7, 5.3 and 8.6 from Parasitology; Association of Applied Biologists for figures 6.9, 8.5 and 9.7 from Annals of Applied Biology; The Society for Experimental Biology for figure 5.5 from Symposia of the Society for Experimental Biology vol. 23; The Company of Biologists Ltd, for figure 2.9 from The Quarterly Journal of Microscopical Science and figures 4.10 and 8.3 from The Journal of Experimental Biology; Dr M. B. Chitwood for figure 1.5 and part of figure 3.3 from An Introduction to Nematology by B. G. and M. B. Chitwood; Hutchinson \& Co. for figures 3.6 and $7.4 B$ 
from Nematodes by H. D. Crofton; E. J. Brill Ltd, for figures 6.8, 9.3 and 9.8 from Nematologica; The University of North Carolina Press for figures 4.6 and 4.9 from Nematology. Fundamentals and Recent Advances with Emphasis on Plant Parasitic and Soil Forms edited by J. N. Sasser and W. R. Jenkins; the Controller of Her Majesty's Stationery Office for part of figures 3.3 and 9.1 from Plant Nematology edited by J. F. Southey; The American Society of Tropical Medicine and Hygiene for figure 7.6 from The American Journal of Tropical Medicine and Hygiene; The Washington Academy of Sciences for figure 9.6 from Journal of the Washington Academy of Sciences; Helminthological Society of Washington for figure 7.1 from Proceedings of the Helminthological Society of Washington; Oliver \& Boyd Ltd, for figures 2.4 and 2.5 from Tissue and Cell; The Rockefeller University Press for figures 7.2 and 7.3 from the Journal of Cell Biology; The Wistar Institute Press for figures 9.2, 9.4 and 9.5 from The Journal of Comparative Neurology and for figure 1.6 from Journal of Morphology; The American Society of Parasitology for part of figure 4.9 from The Journal of Parasitology; R. B. Clark for part of figure 8.1 from Dynamics of Metazoan Evolution; Annual Reviews Inc. for figures 3.8, 8.2, 8.4 and 8.9 from Annual Reviews of Phytopathology; H. R. Wallace and Edward Arnold (Publishers) Ltd., for figure 8.7 from The Biology of Plant Parasitic Nematodes; The American Society of Zoologists for figure 7.4 from American Zoologist. The U.S. National Academy of Sciences for table 9.2 from Proceedings of the National Academy of Sciences, U.S.A.; W. B. Saunders Co. and C. L. Prosser for table 9.1 from Comparative Animal Physiology; Birkhäuser Verlag for figure 7.5 from Experimentia.

Acknowledgements are made to authors by mentioning their names in the legend of the figures.

December 1975

D. L. Lee

H. J. Atkinson 